IRA International Journal of Management \& Social Sciences

ISSN 2455-2267; Vol.08, Issue 02 (August 2017)

Pg. no. 206-212

Institute of Research Advances

http://research-advances.org/index.php/RAJMSS

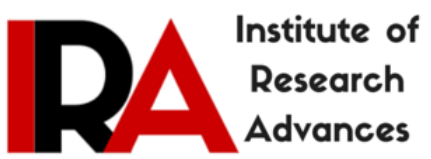

\title{
The Influence of Financial Resources on the Success of Start-up Business in Kenya
}

\author{
Martin Onsiro Ronald, $\mathrm{PhD}$ \\ Senior Lecturer \\ Mount Kenya University, Kenya.
}

Type of Review: Peer Reviewed.

DOI: http://dx.doi.org/10.21013/jmss.v8.n2.p8

\section{How to cite this paper:}

Ronald, M. (2017). The Influence of Financial Resources on the Success of Start-up Business in Kenya. IRAInternational Journal of Management \& Social Sciences (ISSN 2455-2267), 8(2), 206-212. doi:http://dx.doi.org/10.21013/jmss.v8.n2.p8

(C) Institute of Research Advances.

\section{(c) $\mathrm{BY}$-NC}

This work is licensed under a Creative Commons Attribution-Non Commercial 4.0 International License subject to proper citation to the publication source of the work.

Disclaimer: The scholarly papers as reviewed and published by the Institute of Research Advances (IRA) are the views and opinions of their respective authors and are not the views or opinions of the IRA. The IRA disclaims of any harm or loss caused due to the published content to any party.

Institute of Research Advances is an institutional publisher member of Publishers Inter Linking Association Inc. (PILA-CrossRef), USA. The institute is an institutional signatory to the Budapest Open Access Initiative, Hungary advocating the open access of scientific and scholarly knowledge. The Institute is a registered content provider under Open Access Initiative Protocol for Metadata Harvesting (OAI-PMH).

The journal is indexed \& included in WorldCat Discovery Service (USA), CrossRef Metadata Search (USA), WorldCat (USA), OCLC (USA), Open J-Gate (India), EZB (Germany) Scilit (Switzerland), Airiti (China), Bielefeld Academic Search Engine (BASE) of Bielefeld University, Germany, PKP Index of Simon Fraser University, Canada. 


\begin{abstract}
It is true that no new business succeeds without a detailed and thorough business plan. A complete plan identifies and quantifies the capital that is likely to be required to reach break-even and beyond. Accounting as a business function and innovative activity has to be understood by entrepreneurs as it provides clear picture of the business success. The purpose of this study is therefore to examine the relationship that exists between availability of financial resources and success of new startup business. The objectives were to examine financial sources influencing success of startup business. Government programmes in place, motivating factors as well as obstacles to success of startup business. The study adopted quantitative and qualitative approaches where descriptive design was used to achieve the study objectives. A sample of 25 was taken from the study area. A questionnaire was used as a research instrument for this study. The study found out that majority of new business use family and friends loan to finance their business. Majority disagreed that there are government programmes that support startup business. Access to finance and legal regulations posted as the most obstacles business is facing. Majority of respondents also reported that opportunity of having job and earning money as the main motivating factor to start new business. The study recommends the government should come up with new innovative programmes that will support startup business. The study concludes that for any business to succeed, regardless of industry or size, has to identify proper sources of finance with government support and proper accounting tools needs to be adopted.
\end{abstract}

Key words: Financial sources, Government programmes, motivating factors, Success and startup business.

\title{
1. Introduction
}

Entrepreneurship is not only an important driver of economic growth, productivity, innovation and employment. It is also a key player in the "cycle of life" of businesses, giving rise to new firms to take the place of those whose influence and relevance are waning. Whoever has started a business knows well, being an entrepreneur is not easy. Entrepreneurs often must fight an uphill battle to get their new ventures off the ground, and many never succeed though there is little doubt about their relative significance.

According to Dockel (2005), it has been recognized all over the world that the small business sector plays an important role in the socioeconomic development of a country and hence there is a need to support its development. Kenya has also felt the urge to promote the sector.

Globally the role of start-ups is vital for job creation, particularly in Kenya, where start-ups create most new jobs. According to Kauffman (2010), Foundation study, firms in their first year of existence create an average of three million jobs annually, whereas net job gain in existing firms was negative for most years during 1976-2010. Without start-ups, no net job growth would have occurred in the United States in certain years during that period. Moreover, during the lower end of the business cycles, job creation at start-ups remains high, while net job losses at existing firms are highly sensitive to the business cycle.

In the European Union according to the European Commission, "new companies, especially SMEs, represent the most important source of new employment" as they create more than four million new jobs in Europe each year. Hence 85 percent of net employment growth during 2002-2010 is attributable to SMEs (EU Commission 2013).

According to the U.S Small Business Administration (SBA), "While poor management is cited most frequently as the reason businesses fail, inadequate or ill-timed financing is a close second." Sometimes it comes down to simple cash flow--many companies have closed their doors because they just couldn't make it another few months until the money came in (SBE 2011)

Small businesses run most effectively when there are systems in place. One of the most important systems for a small business is an accounting system. Your accounting system is necessary in order to create and manage your budget, set your rates, conduct business with others, and file your taxes. You can set up your accounting system yourself, or hire an accountant to take away some of the guesswork (Alyssa Gregory 2015). Therefore starting a 
business often requires entrepreneurs to understand and complete a variety of business functions. An important business function when starting a small business is accounting. Although many entrepreneurs may be fearful of dredging through endless stacks of financial documents, accounting often provides them with the clearest picture of their business' success. Entrepreneurs must also keep copious amounts of records regarding the small business startup for tax and legal purposes.

Entrepreneurs may also need to provide banks, lenders or investors with a financial forecast relating to the new small business venture. This information is essential for obtaining outside financing for business startup costs. Entrepreneurs usually write a business plan, which includes an economic forecast, expected startup and monthly expenditures, and pro forma financial statements. This accounting information is heavily relied upon by lenders or investors to ensure the entrepreneur have accurate and reliable picture of financial expectations (Osmond, 2015).

\section{Problem statement}

Supply and access to capital are critical to stimulating entrepreneurship and economic growth. The International Finance Corporation estimates that up to $84 \%$ of small and medium-sized enterprises (SMEs) in Africa are either unserved or underserved, representing a value gap in credit financing of USD 140-170 billion (Barriers to Finance Africa's SMEs, ABN 2011 Digital, 2011.)

In Kenya some business startups have problems in raising capital. As there are many sources available, identifying the most probable becomes a challenge. Among other obstacles, other than raising capital, competition, business space and tax burden are experienced. Realizing the key motivation to start a business is another challenge, because some businesses do not have sufficient business plan and goals and normally this makes business to die prematurely.

\section{Purpose and objectives of the study}

The main purpose of this study is to look at the influence of major financial sources on the success of startup business in Kenya. The specific objectives that guided the study were:

(i) To examine the major sources of finance influencing the success of startup business in Kenya

(ii) To evaluate the effect of government programmes in place on success of startup business in Kenya

(iii) To identify major motivating factors as well as obstacles to startup business in Kenya

\section{Methodology}

The study used both qualitative and quantitative approaches whereby descriptive research design was used in order to achieve the study objectives. The universe of the study was the start-up businesses that were registered from Etago sub-county. The population was stratified by nature of business to reflect the distribution of various activities and category of business. A total of 23 respondents were selected using simple random sampling from a total population of 44 .

The research instrument adopted was the questionnaire with both open and closed ended questions. The questions were modified to conform to the research objectives of the study.

Using pilot data, the reliability of 0.81 and 0.88 was established for the instruments. The reliability was calculated by the aid of Cronbach's Coefficients Alphas. The items were rated on a three Likert type scale ranging from $1=$ Agree to $3=$ disagree with $2=$ neither agree nor disagree. The data was analyzed to provide frequencies, percentages, means and standard deviation to describe the population.

\section{Literature}

Brinders, Memela and Mlosy (2003) observes that the major prerequisite for a thriving small-scale enterprise sector is an enabling environment, which includes political and economic stability, market-based incentives and access to 
the resources needed to survive and grow. Biggs (2001), finance has arguably been accepted to be a major obstacle to small, medium, and micro size enterprise growth and survival. In line with Robertson study, Rogerson (2006) found that the issue of finance was prevalent during the stat-up phase regardless of the business sector.

Small business development literature argues that Small medium and micro size enterprise make unique contributions to the economy, with a contribution to GDP, employment and poverty reduction being the most stated (biggs, 2001).

Entrepreneurs believe specific actions can have a significant and positive impacts on their ability to grow and create jobs-but only if these actions are implemented with the required scale. (Young Entrepreneur's Alliance Summit 2013).

\section{Findings and Discussions}

\section{Type of ownership}

On realizing its simplicity in the formation of a business firm, sole proprietorship as more than $65 \%$ was preferred while an equal distribution of $17.4 \%$ were in partnership as well as others respectively as noted in table 1 below. Most of the startups businesses 12(52.2\%) were in pre-start period, while 10(43.5\%) were in operation for a period between $1-5$ years.

Table 1: Type of ownership

\begin{tabular}{lll}
\hline & Frequency & Percent \\
\hline Sole proprietorship & 15 & 65.2 \\
Partnership firm & 4 & 17.4 \\
Others & 4 & 17.4 \\
Total & 23 & 100 \\
\hline
\end{tabular}

Main Activity

From table 2 below it can be noted that majority $47.8 \%$ of the start-ups were engaged in retail trade business followed by engagement in agriculture business $30.4 \%$, while $8.7 \%$ were engaged in transport and financial services. These were attributed due to their simplicity in starting and not being legal entities. None of the respondents was engaged in wholesales, real estate, Professional, scientific or technical services, Healthcare and social assistance may be due to huge financial requirement.

Table 2: Main activity of business

\begin{tabular}{lll}
\hline & Frequency & Percent \\
\hline Retail trade & 11 & 47.8 \\
Transport & 2 & 8.7 \\
Agriculture & 7 & 30.4 \\
Financial services & 2 & 8.7 \\
Educational services & 1 & 4.3 \\
Total & $\mathbf{2 3}$ & $\mathbf{1 0 0 . 0}$ \\
\hline
\end{tabular}

\section{Major sources of financing business}

The problem of raising capital is always primordial for any business activity and was not different with start-up businesses in the study area. Majority $73.9 \%$ believe that it is not easy to get resources to start new business, where as $26.1 \%$ believe it is easy. From table 3 below, it was noted that the main sources of capital for start-ups in the study area is self-financing with a mean of 1.0870 and standard deviation 0.41703 , followed by family and friends with a mean of 1.4348 and standard deviation of 0.72777 . The third main source identified was private lending with a mean and standard deviation of 1.6087 and 0.89133 respectively. The study findings reveal that majority respondents $95.7 \%$, agreed to have used self-funding as the major source in financing their business. These findings concur with Omidya Network (2013), that Afro-entrepreneurs use self-finance and family loans as the main sources 
of funding their businesses. However, currently the main sources of capital for small growing enterprises are retained earnings, credit cards, loan associations and investments from family and friends.

Table 3: Major sources of financing business

\begin{tabular}{lllll}
\hline & N & Mean & $\begin{array}{l}\text { Std. } \\
\text { Deviation }\end{array}$ & Inference \\
\hline Self-funding & 23 & 1.0870 & .41703 & Agree \\
Bank loans & 23 & 2.0435 & .92826 & Disagree \\
Private lending & 23 & 1.6087 & .89133 & Agree \\
Family and friends & 23 & 1.4348 & .72777 & Agree \\
Selling assets & 23 & 2.2609 & 1.05388 & Disagree \\
Credit cards & 23 & 2.4348 & .89575 & Disagree \\
Angel investors & 23 & 2.6087 & .65638 & Disagree \\
Venture capital & 23 & 1.6957 & .92612 & Agree \\
Grants from Government & 23 & 2.6087 & .65638 & Disagree \\
\hline
\end{tabular}

\section{Trend of business}

The respondents were enquired if their business had increased, decreased or remained unchanged over the last six months. The findings in table 4 revealed that most of the business turnover had increased by $73.9 \%$, labour had increased by $52.2 \%$ while $82.6 \%$ and $65.2 \%$ respectively revealed that profit margin as well as Assets had increased over the period. The positive increment of turnover, labour, profit and assets was attributed to good financial management.

Table 4: Trend of business

\begin{tabular}{llllllll}
\hline Sn & Item & $\mathbf{N}$ & Increased & Unchanged & Increased & Mean & Std. Dev. \\
\hline 1 & Turnover & 23 & 17 & 6 & 0 & 1.2609 & .44898 \\
& & $(100)$ & $(73.9)$ & $(26.1)$ & $(0)$ & & \\
2 & Labor & 23 & 12 & 10 & 1 & 1.5217 & .59311 \\
& & $(100)$ & $(52.2)$ & $(43.5)$ & $(4.3)$ & & \\
3 & Profit mark-up & 23 & 19 & 4 & 0 & 1.1739 & .38755 \\
& & $(100)$ & $(82.6)$ & $(17.4)$ & $(0)$ & & \\
4 & Assets & 23 & 15 & 7 & 1 & 1.3913 & .58303 \\
& & $(100)$ & $(65.2)$ & $(30.4)$ & $(4.3)$ & & \\
\hline
\end{tabular}

\section{Government programmes}

Table 5: Opinion on Government programmes

\begin{tabular}{llc}
\hline & Frequency & percent \\
\hline Agree & 5 & 21.7 \\
Neutral & 5 & 21.7 \\
Disagree & 13 & 56.5 \\
Total & $\mathbf{2 3}$ & $\mathbf{1 0 0 . 0}$ \\
\hline
\end{tabular}

African governments have increased their support for entrepreneurs by creating several initiatives to encourage small businesses such as Small Industrial Development Organization (SIDO) in Tanzania, Youth Enterprise Development Fund (YEDF) and Uwezo fund in Kenya among others. However the study findings in table 5 above reveal that majority of respondents $56.5 \%$ believe that the government has not put in place sufficient programmes to support new firms. The findings were attributed to lack of awareness and accesses to information as to what kind of programmes have been put in place. 


\section{Obstacles for business start-ups}

A further investigation into the most pressing obstacles for new start-up businesses was sought. The results have been provided in table 6 below.

\begin{tabular}{lcclc}
\hline & N & Mean & $\begin{array}{l}\text { Std. } \\
\text { Deviation }\end{array}$ & Inference \\
\hline Access to finance & 23 & 1.0435 & .20851 & Agree \\
Finding customer & 23 & 1.5652 & .72777 & Agree \\
Legal regulatory & 23 & 1.3043 & .70290 & Agree \\
Lack of business space & 23 & 1.6957 & .82212 & Agree \\
Acquisition of skills & 23 & 1.6087 & .89133 & Agree \\
Lack of business-related matters & 23 & 1.4783 & .73048 & Agree \\
Lack of skilled employees & 23 & 2.2174 & .95139 & Disagree \\
Access to appropriate technology & 23 & 1.4348 & .78775 & Agree \\
Tax burden & 23 & 1.1739 & .49103 & Agree \\
Cost of production & 23 & 1.3478 & .64728 & Agree \\
Competition & 23 & 1.1739 & .49103 & Agree \\
Others & 23 & 1.1739 & .49103 & Agree \\
\hline
\end{tabular}

The table above reveals that access to finance is the most challenge to new start-up businesses with a mean of 1.0435 and standard deviation of 0.22851 . This was agreed by $95.7 \%$ of the respondents. The second most challenges felt by start-ups were tax burden and competition with a mean score of 1.1739 and standard deviation of 0.49103 each respectively. Legal statutory is also felt as an impediment for new start-ups at a mean score of 1.3043 and standard deviation of 0.70290 respectively.

\section{Motivation for starting new business}

It can be seen from the statistics that a greater majority of start-up business owners are motivated by a number of factor. Majority revealed that desirable career choices as well as gaining new experience and knowledge are the key motivating factors with a mean score of 1.13043 each and standard deviation of 0.45770 and 0.34435 respectively. Others felt motivated to start new businesses as self-challenging while others were due to a feeling of being selfindependent and having flexible working hours.

\begin{tabular}{lllll}
\hline & N & Mean & Std. Deviation & Inference \\
\hline Opportunity of having job & 23 & 1.4783 & .79026 & Agree \\
Being financially independent & 23 & 1.3043 & .63495 & Agree \\
New experience and knowledge & 23 & 1.1304 & .34435 & Agree \\
Flexible working hours & 23 & 1.3478 & .71406 & Agree \\
Self-challenging & 23 & 1.2609 & .61919 & Agree \\
Appropriate way to be wealthy & 23 & 1.9565 & .92826 & Agree \\
It's a desirable career choice & 23 & 1.1304 & .45770 & Agree \\
\hline
\end{tabular}

\section{Conclusions}

There are a variety of options in obtaining finances for starting small business. Such options are like; self-funding, bank loans, private lending, family friends, selling of assets, credit cards, angel investors, venture capital and grants from the government. The most preferred in the study were self-raising and borrowings from family and friends. The start-ups need to venture into other options in raising their capital and this can be achieved by having proper business plan and identify various sources of such funds. Availability of financial resources influences innovation because access to capital allows an innovator to follow the normal path of developing the new product before selling it to others.

Globally, most countries have put in place programmes that can support small entrepreneurs. Kenya has not been left behind in this aspect as there are many programmes among them being Youth Enterprise Development Fund, Uwezo Fund and increase of microfinance institutions. Most people have not enjoyed or accessed the programmes 
due to lack of information and awareness. The government having put such programmes in place should try to initiate creation of awareness and provide full information to young business start-ups as well as to those interested to venture into small business. Governments also have a role to play in encouraging entrepreneurial innovation, but this role is changing with the rise of digital entrepreneurship.

Individuals are motivated to start-up business by different factors. Career choice was felt to be the major motivating factor followed by gaining experience and knowledge. Some other start-ups are motivated as the feel is a way of becoming self-independent as well as having flexible working hours. A very large majority of entrepreneurs are optimistic about their ability to drive growth and job creation in the coming years, whether based in mature or emerging markets. This should be among the driving forces in starting up the business.

\section{Recommendation}

Governments need to do all they can to support fledgling entrepreneurs and remove the barriers that unnecessarily constrain them. The government should create a regulatory environment conducive to conducting business. It should endeavor to provide education opportunities for the acquisition of technical and professional skills and entrepreneurial education sensitizing for young people in a way that could encourage them to enter business and acquire a culture of entrepreneurship.

\section{References}

[1] Kauffman (2010), Foundation Research Series: The Importance of Startups in Job Creation and destruction, July 2010 and US Census Bureau Business Dynamics Statistics.

[2] Omidya Network (2013), accelerating entrepreneurship in Africa

[3] “Entrepreneurship (2020), Action Plan", EU Commission, January 2013.

[4] Young Entrepreneur's Alliance Summit (2013), Entrepreneurial innovation: how to unleash a key source of growth at jobs in the G20 Countries.

[5] Osmond Vitez (2015), http://smallbusiness.chron.com/accounting-important-start-up-business-52.html.

[6] Alyssa,Gregory(2015)http://sbinformation.about.com/od/startingabusiness/a/How-To-Start-ABusiness.htm

[7] ABN Digital (2011), Barriers to Finance Africa's SMEs, ABN Digital, 2011, in Omidyar. Net Work and Monitor Group (2013) accelerating entrepreneurship in Africa

[8] Dockel, M. (2005). SMMES: do they live up to the expectations? Management today, year book: 57-61, March.

[9] Rogerson C. M. (2006). Developing SMMEs in Peripheral Spaces; the Experience of the Free State Province South Africa. South Africa Geographical Journal, 88(6)66-78.

[10] Brinders J., Mamela, B. \& Mlosy, C.D. (2003). African Renaissance 2003: Entrepreneurship and Small Business Management Development in Africa.

[11] Biggs, M. (1997).Getting into GEAR: Government and the economy. Cape Town: UCIT Press.

[12] Robertson K. Tengeh, (2013). Advancing the case for the support and promotion of African immigrant-owned businesses in South Africa. Mediterranean Journal of Social Science Vol. 4, No. 2 May. 